\title{
LOCALIZED ISLAM(S): INTERPRETING AGENTS, COMPETING NARRATIVES AND EXPERIENCES OF FAITH
}

\author{
Arolda Elbasani \\ New York University, Centre for European and Mediterranean Studies, NYC \\ Contact Email: arolda.elbasani@eui.eu \\ Jelena Tošić \\ Unversity of Vienna, Department of Social and Cultural Anthropology, Vienna
}

\begin{abstract}
This special issue investigates contemporary transformations of Islam in the post-communist Balkans. We put forward the concept of localized Islam, as an analytical lens that aptly captures the input of various interpreting agents, competing narratives and choices of faith. By adopting an agent-based approach that is sensitive to relevant actors' choices and the contexts where they operate, we explore how various groups negotiate and ultimately localize the grand Islamic tradition, depending on where they are situated along the hierarchy of power. Specifically we outline three sets of actors and related narratives to revival of Islamic faith - 1) political elites, mainstream intellectuals, and religious hierarchies often unite in safeguarding a nation-centric understanding of religion; 2) foreign networks and missionaries make use of open channels of communication to propagate their specific interpretations and agendas ; and 3) lay-believers who can choose among different offers and rally around the living dimension of religious practice. Contributions in this issue bring ample evidence of multiple actors' strategies, related perspectives and contingent choices of being a Muslim. Case studies include political debates on mosque construction in Athens; political narratives that underpin the construction of the museum of the father of Ataturk in Western Macedonia; politicians and imams' competing interpretations of Syrian war in Kosovo, Macedonia and Albania; the emergence of practice communities that perform Muslim identity in Bulgaria; the particular codes of sharia dating in post-war Sarajevo; and veneration of saints among Muslim Romas in different urban areas in the Balkans.
\end{abstract}

Keywords: Islam, localization, nationalism, radical Islam, living religion 


\section{Introduction}

Following the dissolution of former Yugoslavia, nationalism and ethnic conflict emerged as the hegemonic paradigms to analyse almost all processes of change unfolding across the Balkans. In this context, the revival of Islam is usually read through collective categories of national "belonging" and "Othering", which insist on clear criteria for inclusion and exclusion between and within specific political units (see, e.g., Mentzel 2000). These categorical terms of inter-communal belonging are now found in the media, political debates and international community's projects, thus, shaping an overarching and self-perpetuating line of discourse (Henig and Bielenin-Lenczowska 2013, 2). So overwhelming is this debate that any new developments and practices of Islam are typically squeezed into a one-size-fits-all category of ethno-religious "belonging". Such parameters then serve to delineate the actual course and future projection of religious experiences. Not only do such clear-cut terms of belonging function as a straightjacket for studying diverse religious discoveries and expressions of Islamic faith, but they also eschew believer's personal choices, amidst alternative offers that crowd the post-communist market of ideas. Specifically, Muslims' attempts to cultivate their pious selves and stake out what it means to be a good Muslim are seen as buttressing intercommunal conflicts and propping up regional- or global-wide security threats (Roy 2015).

Yet, the lifting of religious restrictions since the early 1990s has unleashed a myriad of new spaces for Muslim believers to discover their faith in novel and unconventional ways. Today's believers have open access to the Internet and international publications from across the world. They may travel abroad to study, make pilgrimages, attend conferences, and follow online sermons and fatwas. Their engagement with globalized Islamic trends flourished also in the context of substantial "foreign direct investment" from Islamic networks keen to gain followers and influence the revival of Islam in the conflict-ridden Balkans. In this competitive marketplace of ideas, believers encounter a myriad of new offers and can weigh up and choose the relevance of each according to their contingent circumstances and individual experiences (Elbasani and Roy 2015a, 9-11). Hence, rather than an ideologically-loaded economic model of supply and demand, the market here refers to the competition that characterizes the open religious field as well as socio-political and historical experiences that determine the "shopping" preferences of the "customers" in question (Pelkmans 2006). 
This special issue investigates contemporary transformations of Islam in the Balkans at the intersection of dominant narratives of national belonging, globalized trends and influences as well as believer's own recasting of such categories according to the socio-political circumstances they face in their post-socialist lives. We assume that believers are not passive recipients of nationalized or foreign-supplied provisos of belonging. Instead, they are agents with the capacity to reimagine and recast these provisos and ultimately what it means to be a "good" Muslim in the reshuffled post-communist context. Hence, we put forward the concept of localized Islam, as an analytical lens that aptly captures the input of various interpreting agents, competing narratives and alternative choices of faith. The lens of localization thus enables us to unpack the role of agency, relevant solutions and the consequential vernacularization of Islam in specific localities where it takes place. The common questions that underlie the contributions in this issue are: Who are the actors that participate in reformulating categories of belonging and the place of Islam in it? How do they envisage, and reimagine, what it means to be a "good" Muslim? And finally, what are the emerging alternatives to "being" Muslim across the contemporary Balkans?

This introductory essay is organised into three sections. Section I introduces the concept of localized Islam and the role of interpreting agents. Section II outlines the participatory actors and related narratives that shape local perspectives to faith - political elites, mainstream intellectuals, and religious hierarchies that often unite to safeguard a nation-centric understanding of religion; foreign networks and missionaries that make use of open channels of communication to gain market "shares"; and lay-believers who encounter different offers and rally around the living dimension of religious knowledge and practice. Section III introduces the case studies and presents some of the main findings.

\section{Localized Islam(s)}

Islam, like the other "great" religious traditions, is a contested and malleable field of meaning, open to multiple interpretations. As Yavuz notes, "it is not only the universal principles of Islam that ground everyday actions, but also the practical and immediate issues, which Muslims confront. Although Islam provides a universal set of principles to make life meaningful, these principles are vernacularized and localized in specific narratives" (Yavuz 2006, 215). Certainly, there is a cluster of core "essentials"- foundational texts and 
interpretative techniques - which are recognised by all those who consider themselves to be Muslims. Nonetheless, religious authorities, intellectuals and lay-believers differ considerably in their interpretation of the core religious doctrine, respective practices and generally what it means to be a "good" Muslim in a particular society and at specific moments in time. As within every religious orthodoxy, the agency of the interpreter recasts and reinvents faith in close interaction with the historical, ideational and material circumstances in which it operates (Elbasani 2016, 255-256). In other words, it is not possible to talk of Islam or Islamic tradition in general, but only about Muslims decoding and living their faith under specific conditions (Kramer 1993). What is required to capture the entangled flow of global, regional, national, historical and contemporary influences that inform localization is empirically-rich research sensitive to motivations of various agents as well as respective narratives and practices in the specific contexts where they unfold.

Hence, we view localization as an analytical lens that is able to transcend essentialised readings of Islam be it as a body of timeless principles resilient to change or a fixed, one-sizefits-all category of belonging. Specifically, the paradigm of localization allows us to explore the actors and the dynamics of vernacularization of the "great" tradition through authoritative reinterpretations of religious principles, the negotiation of meaning and the pursuit of everyday dimension of religious practice and ritual. This approach necessarily brings to the fore different agents who are endowed with specific resources and who embrace different strategies in their daily political struggles (Escobar 2001). It also highlights competing accounts of Islam in terms of both relevant power struggles and claims on "the proper" way to being Muslim in different locations and at different times (Asad 1986, 15-17). In sum, our agency-focused approach to the localization of Islam allows us to unpack the "grand" religious tradition according to the interpretation of purposeful agents, each flashing their own sources, perspectives and solutions on how to be a Muslim.

\section{Local Agents and Competing Narratives in Post-Communist Balkans}

The collapse of communism, and its restrictive religious policies, provided a key juncture for the recovery of religious ideals and practices across the post-communist realm. Indeed, the liberalization of religious restrictions prompted nothing less than a resurgence of faith (Ramet 2014). Islam was no exception and gradually emerged as a useful source to reimagine the 
community and to make sense of a rapidly changing world, particularly in the context of violent conflicts, changing borders and the creation of new polities that marked the collapse of Yugoslavia. This resurgence of religion went hand-in-hand with the intrusion of a myriad of foreign networks, which enlarged the scope of available religious alternatives (Elbasani $2015,12-13)$. The surfacing options pitted against each other various offers of faith: nationcentric interpretations, which gained fervour in the wake of unfolding conflicts; globalized trends that arrived with foreign networks; and more personalized choices embraced by local believers in the process of religious ritual and observance.

\section{The Prevailing Politics of National Identity}

On the macro political level, nationalism as stirred by post-communist political entrepreneurs emerged as the foremost paradigm to framing battles for state authority, power, territory, and independent statehood during the Balkan conflicts (Poulton and Taji-Farouki 1997; Duijzings 2000). Nationalism as an ideology, often infused with ethno-religious overtones, has historically been a powerful dimension of Balkan politics, but it gained strength during the new wave of post-communist conflicts. In the revived spectrum of Balkan nationalisms, moreover, Muslims were typically depicted as remnants of a bygone era, the "Other" that could hardly integrate into the aspiring uniform, European and often exclusively ChristianOrthodox national units (Carmichael 2002). The anti-Islamic penchant of nationalist discourses was further rooted in the official memories of post-Ottoman nation-and statebuilding experiences, thus linking the past and the present. To be sure, since their very inception, Balkan states that carved themselves out of former Ottoman territories adopted largely antagonistic policies towards their "inherited" Muslims, which were treated as foreigners to be expelled, were stigmatized by the dominant ethno-religious group, became target of forced homogenization or at best toleration as a separate, but difficult to absorb ethno-religious group. Even Muslim-majority Albania renounced Muslim symbols as a synonym of backwardness, and undertook large-scale reforms to remould the Islamic community according to its "modern" and "European times" especially during the interwar period (Clayer 2008; Elbasani and Puto 2016).

State-sponsored academic institutions and intelligentsias often collaborated in legitimizing state policies by providing convenient narratives of uniform national aspirations, past, present and future (Bougarel 2005, 11). These politically-subservient, and oft-fabricated, accounts of 
national "heritage" and how Islam merged or parted ways, came in handy to fashion national projects that dominated the political scene after communism. From Serbia to Macedonia, to Bosnia, and to Kosovo, post-communist elites capitalized on selective historical narratives in order to forge new political entities, consolidate power, and, when necessary, wage wars against the "Others". Government-sponsored Islam - an organizational concept, which refers to the creation of centralized hierarchies collaborating with the state - served as yet another powerful interlocutor of nation-centric accounts merging the past and the present (Oktem 2011, 162-3; Elbasani 2015, 6-8). Accordingly, the state nourished close relationship with nationalized Islamic structures by offering specific benefits and institutional support. In return, the state maintained the prerogative to intervene - ulamas were domesticated, religious ideas were tamed, and scholarship was corrected.

The chains of transmission from the political elite to the Islamic establishment work in a topdown manner: political elites and state bureaucrats establish the institutional and ideological parameters that conform to the idea of the nation; mainstream intellectuals furnish selective historical "memories"; and the religious hierarchies diffuse the official line across the respective community of believers (Elbasani and Roy 2015b, 8, 246). Meanwhile, nationalist and post-conflict paradigms that continue to dominate the study of the Balkans help establish a hegemonic interpretation of the Muslim community as trapped into the politics of communal identity (Henig and Bielenin-Lenczowska 2013,2) and/or official memories of nation- and state-building process (Blumi 1998; Tošić 2015). Hence, Muslims' re-discovery of piety and observance, as well as referents of faith are commonly filtered through the classification schemes that the nationally-organised religious "field" nourishes and animates. These categories necessarily produce inflexible boundaries between and within Islam, while new religious practices raise suspicion of extraterritorial allegiances, anti-democratic tendencies, and threats of terrorism (Khalid 2007; Merdjanova 2013).

\section{Foreign Movements and the Open-Market of Ideas}

Fears of a new, alien and possibly radical Islam gained ground particularly with the arrival of global Islamic movements that brought in ample financial assistance together with their own ideas and agendas for the recovery of Islam (Karcic 2010; Elbasani 2016). In this context, defensive nationalisms and memories of the past proved useful to enforce the narrative of a looming Islamic "threat" and more generally the securitization of Islam (Blumi 1998). 
Subsequently, the role of external "disturbances" frequently instigated exaggeration and hyperbole. As Bougarel puts it, "Some conjured up visions of a 'green diagonal' penetrating the flank of a Christian Europe; others referred to 'European Islam'...lost in an ocean of Orthodox fanaticism. ... Both [perspectives] represent the Balkan Muslim populations as a homogenous and stable whole" $(2003,346)$.

Indeed, new channels of communication with the world created an open and active "marketplace", where foreign actors - missionaries, migrants, foreign students, humanitarian organisations and virtual Internet networks - compete with official institutions and national ideologies for market "shares" (Elbasani 2016; Karčić 2010). Cash-rich Arab foundations, but also other Middle Eastern and Turkish organisations, were particularly active in targeting Muslim communities in the Balkans. Foreign movements, however, were themselves divided into two main competing rifts (Roy 2015). The first was Salafism, either in an institutional form, largely sponsored by Saudi Arabia, or in a de-institutionalized form, driven by informal networks, including individual imams and militant missionaries. The second was the neoOttoman model, sponsored by Turkish official state structures (TIKKA and Diyanet) or nonofficial institutions, such as the Gülen networks. Both trends were further internally divided into separate schools and networks propagating different interpretations of Islam. Despite their differences, external actors enabled new channels for the discovery of Islam by providing funds for the impoverished communities; building new infrastructure; offering scholarships for studying theology abroad, funding translation of foreign literature and sophisticated theological debates; creating new educational institutions; and hosting numerous conferences, workshops, Quran courses and so forth. Additionally, the Internet and online discussion forums served as easily accessible channels to "learn" Islam from different sources (Olson 2015). At least a fraction of these movements also entertained a broader plan to "purify" Islamic practices from local "inventions", while attempting to forge partnerships with specific political groups, and setting up militant cells able to operating across regional and European borders (Elbasani 2016).

Owing to the multiplicity of interpretations on offer, lay believers were confronted with various tendencies, experiences and political agendas, including ones propagated by militant networks. Some of the fringe radical groups managed to infiltrate local institutions, made inroads amongst the poor, attracted groupings suffering the hardship of transition and articulated a message of equality and justice during critical moments of war and the 
withdrawal of the state (Ghodsee 2010). Yet, not all the networks and ideas, which permeated the open market of religion, were similarly welcomed by local communities. Salafi and other radical forms of Islam achieved very limited gains even amongst believers in search of knowledge and practices different from the national-traditional ones (Bougarel 2003; Tošić 2015; Mesarič 2015). In fact, the dilemmas that came with foreign movements and their agendas did, more often than not, trigger soul-searching among Muslim authorities, believers and broad communities on what is to be a "good" Muslim and how to pursue it in the context of their plural and largely secular societies (Karić 2002).

\section{Living Experiences of Faith}

Believers' timid response towards circulating macro-political narratives - national or extraterritorial - shows that they are not passive recipients of collective identities and schemes of belonging. They certainly engage with the socio-political contingencies that affect their individual and communal lives. They also are keen to lead a religious life informed by religious practice and ritual. In the post-communist open-market of ideas, however, they encounter different sources of identification and can weigh up the value of each according to the circumstances of time and place. They can, moreover, avail of different opportunities and networks to learn "the right" ways of incorporating their faith in their daily lives. Rituals and living practices often function as a means to de-authorize hegemonic perspectives that privilege collective identities and authentic orthodoxies (Creed 2011). Hence the notion of everyday Islam and lived experiences appear as a meaningful alternative to the formal, orthodox and community-based narratives (Schielke and Debevec 2012, 2).

On the level of living religiosity or the way an individual experiences his/her relation to faith, then we expect a revision of "identities" be it in terms of ethno-religious belonging, alignment with the global Ummah, gamut of religious experiences and absorption of radical ideologies. Anthropological studies on the Balkans furnish ample evidence of different ways of "being" Muslim (Bringa 1995; Ghodsee 2010). The more one moves beyond and away from centrallyorganised religious "fields", the more one observes Muslim "anomalies" - ethno-religious fusion, heterodox practices, cultural diffusion and plural forms of belonging and believing (Henig and Bielenin-Lenczowska 2013). Mixed identity choices are frequent, particularly in more peripheral settings where ecclesiastical organisations and state institutions are less active in reaching and determining believer's preferences. Hence, seen from the autonomous 
spaces of believer's piety and ritual, the experience of Islam is fluid and dynamic, while Muslim identities mixed, ambiguous and situational. As a recent study puts it, Muslim religiosities in the post-communist Balkans are "increasingly personal, mobile, weakly institutionalized and collective as a choice" (Elbasani and Roy 2015b, 458).

These mobile and personal forms of religiosity often congregate into autonomous practice communities, informal structures where members of an ethno-national group or sub-group endeavour to build a community of believers within a larger group of "cultural Muslims" (Roy 2004). Believers aim to define a religious attitude towards the world that does not consist of "belonging" to a cultural group, but rather of freely incorporating religious norms in their daily lives. They do not necessarily reject the concept of local traditions, nor do they consider their less observant neighbours as "infidels". They also do not seek institutional legitimacy or authority. Yet, the emerging faith communities share a common interest in learning, organising meetings, attending related forums and practicing together (Olson 2016). In doing so, they are open to and incorporate different references - local, national and global.

\section{Summary of the Articles and Findings}

The articles in this issue aim to shed light on the role of various agents and the emerging alternatives and choices of being Muslim in different cases across the post-communist Balkans. By adopting an agent-based approach that is sensitive to relevant actors' choices and the contexts where they operate, we explore how various groups negotiate and ultimately localize the grand Islamic tradition, depending on where they are situated along the hierarchy of power.

At least two articles in this issue analyse religion as a power-laden construct that portrays a hegemonic political discourse of historical memories, collective national identities, and communal belonging. Alexandros Sakellarious' contribution explores both continuities and discontinuities in the contemporary political discourse on Islam by focusing on the parliamentary debates regarding the construction of a mosque in Athens (2016). He situates his analysis in the dominant narrative of post-Ottoman nation- and state-building project but also the historical affinity between the Orthodox Church and the Greek collective identity, both crucial to explain the prevailing fear that dominates political debates on the mosque 
construction, and the presence of Islam in Greece more broadly. By elaborating on the intricacies of the evolving political discourse, Sakellarious shows that various agents particularly the extreme right parties, specific media outlets, and a section of the Greek Orthodox Church - deploy selected historical narratives to construe an image of Islam as a threat to the social cohesion. Tracing these discursive genealogies allows the author to grasp how a specific segment of the political spectrum incites moral/religious panic while reducing Islam to the Greek "traditional" and more recently to the "fundamentalist" Other. Nonetheless, the analysis also shows that the actual discourse that capitalizes on past narratives, changes and evolves depending on (trans)national events and their implications for the country under study. Of particular interest here is the intersection of the position of Greek extreme right towards building the mosque in Athens with the wider discourses on multiculturalism and it backlashes in western Europe (Wessendorf and Vertovec 2009). Waves of immigration, the threat of terrorism linked to Islam and the rising power of Turkey, a much feared neighbour in Greece, unsurprisingly reinforce existing fears and backlashes.

Similarly, Anna Zadrozna's article highlights the importance of the Ottoman legacy, including the more recent Neo-Ottoman ideology, as the prime discursive horizon for understanding the political appropriation of Islam and Turkish-ness during the opening of the Memory House of Ali Riza Efendi (the father of Mustafa Kemal Atatürk) in western Macedonia (2016). Funded by the Turkish government and opened in 2014, the memory house serves as a site for remembering and forgetting by recalling politically-suitable events, while silencing others. Inspired by Nora's lieux de memoire (1989) Zadrozna shows how the narrative of Turkish-ness develops within the quest of the Macedonian political elite to gain international standing and Turkey's efforts to revive its cultural, political and economic presence in the former Ottoman space. Here, the transnational influences not only enter the ethno-national frictions of identity politics, whereas local Muslims identify as Turks, Macedonians and/or Torbeshi, but it also adds a new dimension by sparking the issue of "ownership" of Atatürk's origin. Of particular interest here is how the exhibition of the house tells the story of a religious and modest family, which resonates with the pro-Islamic agenda of the actual Turkish government but contrasts with Atatürk's oft-publicized stanch secular image. Furthermore, as Zadrozna cunningly uncovers from her local interlocutors, the memory house awakens struggles for identity and power but also suspicion regarding such political projects and related motives. 
Whereas history and memory are usually the exclusive arena of politicians' efforts to regulate religious life and practice, Islamic authorities - formal and informal - can avail of open spaces of knowledge to discover and debate the "proper" prerogatives of faith. It is in these alternative and dynamic spaces, enabled by the Internet, but also substantial foreign "direct investment" from global Islamic networks, that believers search for the most appropriate ways of being Muslim. Behar Sadriu's contribution on Albanian's approach to the war in Syria unravels a disconnect between politicians, who view the issue within national cum security frames that follow closely western policy shifts; and a select group of imams, who view it within their country's reputable past as part of the Ottoman Empire and/or as a recent revival of Muslim Ummah (2016). Rhetorically - and also physically - participating in the war in Syria here appears as the way to reclaim the role of Albanians within the Muslim world after decades of imposed atheism and a stringent national-political discourse on the place of Islam. By analysing debates and commentaries of political actors, the media and selected imams concerned with the involvement of Albanian fighters in the Syrian war, Sadriu unravels the complexity and sometimes contradictory positions of different actors in negotiating the role of Islam in Albania, Kosovo and Macedonia. The analysis demonstrates how political and religious claims are deeply entangled and continuously shift between different spatiotemporal registers: the Ottoman Empire, colonial re-drawings of borders in the Middle East, the socialist and post-Yugoslav legacy, recent power dynamics in Southeast Europe (SEE) and the Middle East as well as the role of eschatology. The agentive dimension Sadriu lays bare in his analysis rests primarily with selected imams, who nourish strong links with Arab countries, challenging the hegemonic and pro-western discursive construction of the Albanian Muslim as a secular and nationalized individual ripped out from his/her Ottoman past and/or connectedness to the global Ummah.

The topic of Muslim believers debating and staking out their own understandings of what it means to be a pious Muslim is taken up in the remaining articles of this issue. Laura Olson analyses how Bulgarian-speaking Muslims congregate into informal groups and perform their "Muslim" identity both through life-style choices and by debating questions of Islamic practice (2016). By using the concept of communities of practice - networks characterised by mutual engagement, a shared repertoire and joint goals - Olson teases out the fluid and constantly negotiated sense of Muslim identity which incorporates local and foreign connotations. The groups of women under observation seemingly embrace a hybrid style of clothing both foreign and local. Young women are particularly adept at negotiating when and 
what type of hijab to wear, with the majority choosing to wear it only to the mosque. Young women are also more apt to wearing Islamic clothing, usually imported from Turkey and Saudi Arabia, which makes the wearer look more worldly than local residents, while underlying her "obvious" orientation towards Middle Eastern style. The crossover between local and global influences features very strongly also in online discussion forums where believers debate various issues related to Islamic knowledge and practice. Altogether, communities of practice enable them to congregate into autonomous and local groups where believers enact their identity by establishing connection with the global community of believers but also resisting the stigma they usually encounter in mainstream Bulgarian society and politics.

The next article by Andreja Mesarič follows a similar line of inquiry when investigating how young pious Muslims negotiate authoritative Islamic texts, personal faith, local traditional practices and wider social norms when trying to lead their lives as believers in post-war Sarajevo (2016). By focusing on the practice of sharia-dating, Mesarič's analysis reveals how pious believers enact their faith but also craft an ethical self in the context of chaotic, divided and tense post-war society, which they believe has lost its moral grounding. Her work breaks through the common binary "diagnoses" of Islamic revival as believers versus non-believers or moderate versus Salafis, typically employed in the studies on the contemporary revival of Islam in the Balkans. Rather, it elaborates on how the experience of becoming a virtuous Muslim evolves at the intersection of power relations, group practices and personal intent. These detracted forms of localization unfold in concrete social spaces - mosques, tekkes, Islamic cafés, civil society organisations or gatherings in private homes - where young believers cultivate their pious selves and enact the everyday dimension of Islamic knowledge and practice. However, rather than looking at these particular modes of social interaction and gender relations as purely "religious", Mesarič's holistic socio-historical analysis portrays an account of sharia-dating as a re-appropriation of the courtship practice (asikovanje) that marked gender relations in Bosnia and other parts of the Balkans across generations and beyond religious boundaries.

Ksenia Trofimova's article elaborates on the new meanings and forms of the popular tradition of veneration of saints, which is a part of everyday religious practice in Romani urban districts across Serbia, Macedonia and Kosovo (2016). By focusing on diverse participating actors - caretakers of shrines, visitors, local spiritual authorities and residents of urban 
Romani settlements - Trofimova traces the agentive dimension of this practice, and how it is reproduced, contested, negotiated and ultimately localized in a specific cultural milieu. The conceptual lens of invented tradition (Hobsbawm and Ranger 2012) adopted in the article enables the author to tease out both historical continuities and recent inventions that mark the contemporary appropriations of this longstanding heterodox Islamic or rather interconfessional practice cultivated in the Balkans. In particular, her analysis of the spatial, material and narrative dimensions associated with the cult of saints points at hybrid and interconfessional interiors of the shrines, specific dress codes, use of visions or dreams as well as references to "convenient historical pasts", especially regarding interpretations of the Ottoman legacy. Here too, popular narratives, beliefs and daily practices associated with venerating saints are much more significant and often contrasts with the "written" religious tradition and Orthodox knowledge guarded by the official Islamic authorities.

Another key, and perhaps counterintuitive finding of this special issue is the active role of women in cultivating a religious self that more often than not transforms, rather than conforms to collective categories of belonging, be it national, political, global and/or authoritatively sanctioned. In that sense the analysis provided in this issue disrupts the hegemonic readings of Islam primarily through the lens of male extremism, gender violence, women oppression, female passivity (see also Abu-Lughod 2013, Zubaida 2011) and/or gender inequality backed by patriarchal interpretations and institutionalized religious order. All the contributions that focus on believers' performance of religious practice - Bulgarianspeaking Muslims' enaction of Islamic practice, Bosnian Muslims' experience of shariadating and Muslim Roma's veneration of saints - underscore the agentive dimension of women's purposeful recasting of "rules of behavior". Women here appear to be participatory actors actively rewriting rather than passively subjecting to "governing" Islamic rules. Indeed, the way female believers pursue Islamic knowledge and practice in their daily lives is an example par excellence of recasting a tradition largely narrated by national aspirations, textual dogma and institutionalized religious order. Not only are the observed religious practices of women context-specific, but they are also deliberate acts of staking out what it means to be a "good Muslim" in their specific socio-political milieus. In Trofimova's analysis of the practice of shrines among Roma communities, women actually perform the role of "ritual authorities" that uphold the heterodox tradition of veneration of saints by maintaining the shrines, elaborating the interior and instructing visitors on the rules of conduct. Olson's observation of communities of practice among Muslims in Bulgaria also shows that women, 
including adolescent women, take on a leading role in organising informal meetings and debating the right way of religious practice. Their dress choices in particular point at a hybrid and personal form of piety and observance: young women tend to prefer fashionable Middle Eastern style hijabs, but they also choose to wear it at religious venues only; their mothers and grandmothers by contrast tend to wear more traditional costumes, typically featuring folk colours and symbolism. Similarly, Mesaric's account of the dating life of Muslim believers in Bosnia highlights women's active role in determining the "religious" boundaries of partnerseeking strategies. Most rules on searching for a marriage partner - the form of introduction, adequate spaces for meeting and socializing, features of Islamic cafés, the level and time of interaction with the prospective husband, the possible change of partners when necessary are all negotiated on the ground and for as long as it takes to find the right match.

Most of women's religious experiences also develop independently, and sometimes, in open contrast to the prescriptions of the institutionalized hierarchy, which is occupied exclusively by men. Trofimova's analysis of shrines shows that women actively confront religious authorities, which tend to disapprove of such practices for having no connection to "proper" Islam. In one case, the female "ritual specialists" crucially figured in defrocking the village Imam, who wanted to clean the interiors of the local school from non-Muslim symbols typically displayed in Roma's houses and praying venues. Mesaric's account of the premarital relations among Muslim believers also displays that women are aware of and confront head on authorities' critique on the legitimacy of such practice in written Islamic sources . Olson's investigation of women in Bulgaria, on the other hand, shows how they organise, meet and practice in informal groups that do not seek any guidance or form of legitimacy from the religious authorities. Most of these women are probably aware that the local authorities would anyway hardly condone the design-your-own kit of Islamic practice that they seeminly choose to observe.

\section{Acknowledgements}

We are grateful for financial support to Robert Schuman Centre for Advanced Studies, (RSCAS), ReligioWest Project, and European Research Council (ERC grant agreement no 269860). We would also like to thank the following individuals for providing helpful comments and feedback: Cecilie Endresen, Fabio Giomi, Myra Waterbury, Olivier Roy and Emma Nyhan. 


\section{References}

Abu-Lughod, Lila. 2013. Do Muslim Women Need Saving? Boston: Harvard University Press. Asad, Talal. 1986. The Idea of an Anthropology of Islam, Occasional Paper Series, Center for Contemporary Arab Studies, Georgetown University.

Blumi, Isa. 1998. "The Commodification of Otherness and the Ethnic Unit in the Balkans: How to Think About Albanians". East European Politics and Societies 12: 527-69.

Bougarel, Xavier. 2003. "Islam and Politics in the Post-Communist Balkans (1990-2000)." In New Approaches to Balkan Studies, edited by Dimitris Keridis and Charles Perry, 345360. Dulles: Brassey's.

Bougarel, Xavier. 2005. The Role of Balkan Muslims in Building European Islam. EPC Issue Paper No. 43.

Bringa, Tone. 1995. Being Muslim the Bosnian Way: Identity and Community in a Central Bosnian Village. Princeton: Princeton University Press.

Carmichael, Cathie. 2002. Ethnic Cleansing in the Balkans: Nationalism and the Destruction of Tradition. London: Routledge.

Clayer, Nathalie. 2008. "Behind the Veil: The Reform of Islam in Inter-War Albania or the Search for a 'Modern' and 'European' Islam." In Islam in Inter-War Europe, edited by Nathalie Clayer and Eric Germain, 128-156. London: Hurst and Company.

Creed, Gerald. 2011. Masquerade and Post-Socialism: Ritual and Culture Dispossession in Bulgaria. Bloomington: Indiana University Press.

Duijzings, Ger. 2000. Religion and the Politics of Identity in Kosovo. London: Hurst and Company.

Elbasani, Arolda. 2015. "Introduction: Nation, State and Faith in the Post-Communist Era." In The Revival of Islam in the Balkans: From Identity to Religiosity, edited by Arolda Elbasani and Olivier Roy, 1-23. Basingstoke: Palgrave Macmillan.

Elbasani, Arolda. 2016. "State-Organised Religion and Muslims' Commitment to Democracy in Albania". Europe-Asia Studies 68 (2): 253-269.

Elbasani, Arolda and Artan Puto. 2017. "Albanian-made Laicite: A Consensual Model for a Plural European Home?" Journal of Balkan and Near Eastern Studies, OnlineFirst: http://dx.doi.org/10.1080/19448953.2016.1201994

Elbasani, Arolda and Olivier Roy. 2015b. "Islam in the Post-Communist Balkans: Alternative Pathways to God". Southeast European and Black Sea Studies, 15(4): 457-471.

Elbasani, Arolda and Olivier Roy. 2015a. The Revival of Islam in the Balkans: From Identity to Religiosity, Basingstoke: Palgrave Macmillan.

Escobar, Arthuro. 2001. "Culture Sits in Places. Reflections on Globalism and Subaltern Strategies of Localization". Political Geography 20(2001): 139-174.

Ghodsee, Kristen. 2010. Muslim Lives in Eastern Europe: Gender, Ethnicity and Transformation of Islam in Post-Socialist Bulgaria. Princeton: Princeton University Press.

Hennig, David and Karolina Bielenin-Lenczowska. 2013. "Recasting Anthropological Perspectives on Islam in Southeast Europe". Anthropological Journal of European Cultures 22(2): 1-11.

Hobsbawm, Eric, and Ranger, Terence. 2012. The Invention of Tradition. New York: Cambridge University Press.

Karčić, Harun. 2010. "Globalization and Islam in Bosnia: Foreign Influences and their Effects". Totalitarian Movements and Political Religions 11(2): 151-66.

Karić, Enes. 2002. 'Is 'Euro- Islam' a Myth, Challenge or a Real Opportunity for Muslims in Europe?" Journal of Muslim Minority Affairs 22(2): 435-42. 
Khalid, Adeeb. 2007. Islam after Communism. Religion and Politics in Central Asia. Berkley: University of California Press.

Kramer, Gudrun. 1993. "Islamist Notions of Democracy". Middle East Report 183 (?): 2-8.

Mentzel, Peter. 2000. "Introduction: Identity, Confessionalism, and Nationalism". Nationalities Papers: The Journal of Nationalism and Ethnicity 28(1): 7-11.

Merdjanova, Inna. 2013. Rediscovering the Umma. Muslims in the Balkans between Nationalism and Transnationalism. Oxford: OUP.

Mesarič, Andreja. 2016. “'Islamic Cafés' and 'Sharia Dating': Muslim Youth, Spaces of Sociability, and Partner Relationships in Bosnia-Herzegovina”. Nationalities Papers: The Journal of Nationalism and Ethnicity, Forthcoming.

Mesarič, Andreja. 2015. "Muslim Women's Dress Practices in Bosnia-Herzegovina:

Localising Islam through Everyday Lived Practice" In The Revival of Islam in the Balkans: From Identity to Religiosity, edited by Arolda Elbasani and Olivier Roy, 103122. Basingstoke: Palgrave Macmillan.

Nora, Pierre. 1989. "Between Memory and History: Les Lieux de Mémoire". Representations 26: 7-24.

Oktem, Kerem. 2011. "Between Emigration, De-Islamization and the Nation-State: Muslim Communities in the Balkans Today". Southeast European and Black Sea Studies 11(2): 15571.

Olson, J. Laura. 2015. "The Multiple Voices of Bulgaria's Unofficial Islamic Leaders." In The Revival of Islam in the Balkans: From Identity to Religiosity, edited by Arolda Elbasani and Olivier Roy, 122-142. Basingstoke: Palgrave Macmillan.

Olson, J. Laura. 2016. "Negotiating Meaning through Costume and Social Media in Bulgarian Muslims' Community of Practice". Nationalities Papers: The Journal of Nationalism and Ethnicity, Forthcoming.

Pelkmans, Mathijs. 2006. "Asymmetries on the 'Religious Market' in Kyrgyzstan." In The Postsocialist Religious Question. Faith and Power in Central Asia and East-Central Europe, edited by Chris Hann and the "Civil Religion" Group, 29-47. Berlin Münster: LIT Verlag.

Poulton, Hought and Suha, Taji-Farouki. 1997. Muslim Identity and the Balkan State. London: Hurst.

Ramet, Sabrina .2014. Religion and Politics in Central and Southeastern Europe: Challenges since 1989. Basingstoke: Palgrave Macmillan.

Roy, Olivier. 2004. Globalized Islam: The Search for a New Ummah. New York: Columbia University Press.

Roy, Olivier. 2015. "Conclusions." In The Revival of Islam in the Balkans: From Identity to Religiosity, edited by Arolda Elbasani and Olivier Roy, 242-252. Basingstoke: Palgrave Macmillan.

Sadriu, Behar. 2016. “ x". Nationalities Papers: The Journal of Nationalism and Ethnicity, Forthcoming.

Sakellarious, Alexander. 2016. "Islam and politics of fear in Greece: Migration, terrorism and 'ghosts' from the past".Nationalities Papers: The Journal of Nationalism and Ethnicity, Forthcoming.

Schielke, Samuli and Lisa Debevec. 2012. Ordinary Lives and Grand Schemes. An Anthropology of Everyday Religion. New York Oxford: Berghahn.

Tošić, Jelena (2015): The Loudspeaker of Faith in the Calm City: Islam and Urban Diversity in Contemporary Balkans, In The Revival of Islam in the Balkans: From Identity to Religiosity, edited by Arolda Elbasani and Olivier Roy, 83-103. Basingstoke: Palgrave Macmillan. 
Trofimova, Ksenia. 2016. "Transforming Islam among Roma communities in the Balkans: a case of popular religiosity". Nationalities Papers: The Journal of Nationalism and Ethnicity, Forthcoming.

Wessendorf, Susanne and Steven Vertovec. 2009. The Multiculturalism Backlash. European Discourses, Policies and Practices. London: Routledge.

Yavuz, Hakan. 2006. "Is There a Turkish Islam? The Emergence of Convergence and Consensus". Journal of Muslim Minority Affairs 24 (2): 213-32.

Zadrożna, Anna. 2016. "Re-Constructing the Past in a Post-Ottoman Village: Turkish-ness in a Transnational Context". Nationalities Papers: The Journal of Nationalism and Ethnicity, Forthcoming.

Zubaida, Sami. 2011. Beyond Islam: A New Understanding of the Middle East. London: Tauris. 